\title{
Arsenic-phosphorus interactions in the soil-plant-microbe system: dynamics of uptake, suppression and toxicity to plants
}

Article

Accepted Version

Creative Commons: Attribution-Noncommercial-No Derivative Works 4.0

Anawar, H. M., Rengel, Z., Damon, P. and Tibbett, M. (2018) Arsenic-phosphorus interactions in the soil-plant-microbe system: dynamics of uptake, suppression and toxicity to plants. Environmental Pollution, 233. pp. 1003-1012. ISSN 0269-7491 doi: https://doi.org/10.1016/j.envpol.2017.09.098 Available at https://centaur.reading.ac.uk/73306/

It is advisable to refer to the publisher's version if you intend to cite from the work. See Guidance on citing.

Published version at: https://doi.org/10.1016/j.envpol.2017.09.098

To link to this article DOI: http://dx.doi.org/10.1016/j.envpol.2017.09.098

Publisher: Elsevier

All outputs in CentAUR are protected by Intellectual Property Rights law, including copyright law. Copyright and IPR is retained by the creators or other copyright holders. Terms and conditions for use of this material are defined in the End User Agreement.

www.reading.ac.uk/centaur 
Central Archive at the University of Reading

Reading's research outputs online 


\section{Arsenic-phosphorus interactions in the soil-plant-microbe}

2 system: dynamics of uptake, suppression and toxicity to plants

3

4

5

6

7

8

9

10

11

12

Hossain M Anawar ${ }^{\mathrm{a} *}$, Zed Rengel $^{\mathrm{a}}$, Paul Damon ${ }^{\mathrm{a}}$, Mark Tibbett ${ }^{\mathrm{b}}$

${ }^{a}$ School of Earth and Environment (M087), The University of Western Australia, Crawley WA 6009, Australia

${ }^{b}$ Centre for Agri-Environmental Research \& Soil Research Centre, School of Agriculture, Policy and Development, University of Reading, RG6 6AR Reading, UK

*Corresponding author

Phone +61-8-6488 1714

Fax +61-08-6488 1050

E-mail: anawar4@hotmail.com

\section{ABSTRACT}

High arsenic (As) concentrations in the soil, water and plant systems can pose a direct health risk to humans and ecosystems. Phosphate (Pi) ions strongly influence As availability in soil, its uptake and toxicity to plants. Better understanding of $\mathrm{As}(\mathrm{V})-\mathrm{Pi}$ interactions in soils and plants will facilitate a potential remediation strategy for As contaminated soils, reducing As uptake by crop plants and toxicity to human populations via manipulation of soil Pi content. However, the As(V)-Pi interactions in soil-plant systems are complex, leading to contradictory findings among different studies. Therefore, this review investigates the role of soil type, soil properties, minerals, Pi levels in soil and plant, Pi transporters, mycorrhizal 
association and microbial activities on As-Pi interactions in soils and hydroponics, and uptake by plants, elucidate the key mechanisms, identify key knowledge gaps and recommend new research directions. Although Pi suppresses As uptake by plants in hydroponic systems, in soils it could either increase or decrease As availability and toxicity to plants depending on the soil types, properties and charge characteristics. In soil, As(V) availability is typically increased by the addition of Pi. At the root surface, the Pi transport system has high affinity for Pi over As(V). However, Pi concentration in plant influences the As transport from roots to shoots. Mycorrhizal association may reduce As uptake via a physiological shift to the mycorrhizal uptake pathway, which has a greater affinity for Pi over $\mathrm{As}(\mathrm{V})$ than the root epidermal uptake pathway.

Capsule: Understanding As-Pi interactions in the soil-plant systems can help in reducing the As uptake by crop plants and protecting the food chain.

Keywords: Arsenic toxicity. As-Pi interactions. As-Pi uptake by plants. Soil mineralogy. Soil types. Mycorrhizal association

\section{Contents}

1. Introduction

\subsection{Arsenic in the environment}

\subsection{As-Pi chemistry and their competition}

\subsection{As-Pi interactions and significance of this review}

2. Influence of soil property, mineralogy and soil types on As and Pi sorption to soils

3. As-Pi interaction, uptake and arsenic toxicity in plants

\subsection{Mechanisms of As toxicity to plants}


3.2. As-Pi interactions and uptake by plants grown in soils

3.3. Impact of Pi availability on As uptake by plants in hydroponics

3.4. Relation of plant P status with As uptake

3.5. High-affinity and low-affinity Pi transporter for Pi and As uptake

\subsection{Effect of root exudates on As and Pi uptake}

3.7. Does As resistance occur via decreased As uptake or protective effect of high Pi uptake?

4. Role of mycorrhiza on As-Pi interaction in soil system and uptake by plant

5. Influence of soil microbial communities on As and Pi uptake by plants

6. Conclusions

7. Recommendations for future work

Acknowledgements

References

\section{Introduction}

\subsection{Arsenic in the environment}

Arsenic is generally considered one of the top priority elements for carcinogenicity and toxicity to humans, animals and plants (ATSDR, 2007). Several severe incidents of As poisoning have occurred in regions such as Bangladesh, India (West Bengal) (Anawar et al., 2002), Vietnam, Taiwan and northwest China (Wang et al., 2002). Sources of high contents of As in the environment are either geogenic in groundwater aquifers (Salmon et al., 2014) or anthropogenic, typically associated with mining, industrial waste and agricultural chemicals (Anawar et al., 2011). Average concentration of As in the Earth's crust is $1.5 \mu \mathrm{g} / \mathrm{g}$ with the median value of $6.0 \mu \mathrm{g}$ As $/ \mathrm{g}$ for uncontaminated soils (Bowen, 1979). The average As contents in agricultural fields that received As-containing pesticides and defoliants range from $5-2553 \mathrm{mg} / \mathrm{kg}$ (Walsh and Kenny, 1975). Early mining and smelting operations led to contamination of the agricultural land, with soil As levels of 539-9380 mg/kg in Korea (Jung 
et al., 2002), 11.1-651.1 mg/kg in Portugal (Pratas et al., 2005), etc. The As concentration in human hair exhibits significant relationship with that in rice (Oryza sativa L.), wheat (Triticum aestivum L.) and agricultural soils (Rahman et al., 2007, 2008) in As-affected areas reflecting human exposure to As via the soil-plant transfer pathways (Geng et al., 2006; Huang et al., 2006). These studies indicate widespread occurrence of As, and its contamination effects on agricultural soils.

\subsection{As-Pi chemistry and their competition}

Under aerobic conditions, As and phosphorus (Pi) form stable tetrahedral oxyanions $(\mathrm{As}(\mathrm{V})$ and orthophosphate, $\mathrm{Pi})$ of ${ }^{+} 5$ oxidation state due to similar chemical characteristics (Manning and Goldberg, 1996; Lambkin and Alloway, 2003). In soil, As predominantly exists in the inorganic forms (arsenate, $\mathrm{As}(\mathrm{V})$ and arsenite, As(III)) with minor concentration of dimethylarsinic acid (DMAA) and monomethylarsenic acid (MMAA) (Pantsar-Kallio and Manninen, 1997; Quaghebeur et al., 2003; Quaghebeur and Rengel, 2005). Because of their physico-chemical similarity, As(V) and Pi ions interact strongly competing for the same charged surfaces in soil. Arsenate uptake by plants occurs via the similar carrier process as $\mathrm{Pi}$ (Pickering et al., 2000; Zhao et al., 2009) with Pi having more affinity for transport sites than As(V) (Ullrich-Eberius et al., 1989; Meharg et al., 1994; Dunlop et al., 1997). For plant growth, Pi is an essential macronutrient. The nucleic acids, phospholipids and ATP contain $\mathrm{Pi}$, that is involved in regulating key enzyme reactions and metabolic pathways (Schachtman et al., 1998; Rose et al., 2013).

\subsection{As-Pi interactions and significance of this review}

A lot of research works have studied the As-Pi interactions in the environment with conflicting results (Vetterlein et al., 2007; Zhao et al., 2009; Szegedi et al., 2010). On one 
hand, Pi can decrease plant As uptake, and on the other hand, it may promote the availability of As in soil and increase plant uptake. Therefore, it is necessary to explore the mechanism of action between As and Pi under different environmental conditions. Most studies, to-date, have failed to account for the complexity of interactions between Pi and As in soil-plant system, and the variability in competition between As and Pi depending on soil types and substrate conditions. Furthermore, the mechanisms of how $\mathrm{Pi}$, when used as fertilizer, ameliorate As toxicity to crop plants (Peryea, 1998) are not yet clear (Geng et al., 2005). Although the major factors have been identified, the net effect of their interactions is poorly understood. Therefore, further research is essential to assess the available knowledge, identify the research gaps for the future work, understand the As-Pi interactions in soil-plant systems, and their effects on exacerbation and/or amelioration of As toxicity, because these results can help to decrease the risk of As toxicity to plants, animals and humans. Therefore, this study reviewed (1) As-Pi interactions in soil-plant continuum, (2) the effect of soil type, soil properties and minerals on As-Pi interaction in soils, (3) the role of different Pi transporters in Pi and As uptake by plants, (4) the mechanisms of As and Pi uptake in As-tolerant and Asintolerant plants, (5) how mycorrhizal symbioses and bacteria influence As and Pi uptake by plants and As toxicity, and (6) case studies of As and Pi uptake by As-tolerant and Asintolerant genotypes, and P-deficient and P-sufficient plants. This review investigates the role of Pi on As uptake and toxicity to plants, elucidate the key mechanisms and factors affecting the As : Pi interactions in soils and plants, identify key knowledge gaps and recommend new research directions.

\section{Influence of soil property, mineralogy and soil types on As and Pi sorption to soils}

Due to a smaller size and higher charge, Pi anions bind to soil more strongly and higher than As(V) (Lambkin and Alloway, 2003) at similar Pi and As concentrations (Woolson et al., 
1973) making more As available by plant uptake (Zou et al., 2009). Due to slow sorption to soil, Pi become more competitive than As(V) over time (Lambkin and Alloway, 2003). According to the Steindorf-Rebhun-Sheintuch equation, ligand exchange theory and a share charge hypothesis, Pi has more probability to replace As(V) from soils (Roy et al., 1986; McBride, 1994). However, Pi could also be desorbed by As due to a mass action effect of high As:Pi concentrations in soil solution (Lambkin and Alloway, 2003). The fast adsorption of As and Pi occurred by exchange adsorption, while slow adsorption by specific adsorption in the acid, neutral and calcareous purple soils (Zou et al., 2009).

The soil mineralogy, soil texture, soil properties and environmental factors that may greatly affect the As-Pi interaction, mobility and availability of As in soils (Bissen and Frimmel, 2003) and uptake by plants include mineral components, presence of anions (e.g., citrate, phosphate, phytates/phytic acid (Dalal, 1977; Marschner, 1995), residence time, pH, redox potential, organic matter $(\mathrm{OM})$, microbial activity and especially, $\mathrm{Fe}$ - and Al-oxide/ hydroxides (Melamed et al., 1995; Turpeinen et al., 1999; Fitz and Wenzel, 2002; Kubicki, 2005). Among these factors, goethite and $\mathrm{pH}$ strongly control the behaviour of As and Pi. Knowledge of $\mathrm{As}(\mathrm{V})$ adsorption on individual soil minerals may predict $\mathrm{As}(\mathrm{V})$ adsorption in whole soils and its response to Pi addition (Manning and Goldberg, 1996). Fordham and Norrish (1979) and Violante and Pigna (2002) found that Fe and Mn-rich minerals such as goethite, nontronite, ferruginous smectites, birnessite and pyrolusite absorbed more As(V) than $\mathrm{Pi}$ when supplied in equal molar ratio, but more $\mathrm{Pi}$ than $\mathrm{As}(\mathrm{V})$ was sorbed on noncrystalline Al containing minerals e.g., gibbsite, boehmite, allophane and clay fractions (e.g., kaolinite, illite and vermiculite) resulting in higher As(V) desorption and uptake by Indian mustard (Brassica juncea L.) (Bolan et al., 2013). A high rate of goethite addition to soils can reduce Pi and As uptake by plants (Vetterlein et al., 2007). The Pi and Fe addition to 
high As soils using a sequential incorporation method can significantly decrease As toxicity to lettuce root growth by supplying a nutrient source (Koo et al., 2013).

In case of sandy soils/sandy loam, Pi addition displaced As(V) ions from the surface of sand grains due to a low number of sorption sites and increased As uptake by plants, thus decreasing plant growth (O’Neill, 1992; Woolson et al., 1973), but increased vegetative yields of wheat, barley, sudangrass and lucerne (Creger and Peryea, 1994) decreasing As uptake and toxicity on a silty clay loam (Woolson et al., 1973), a silty loam (Jacobs and Keeney, 1970) and clay loam and sandy clay loam soils (Pigna et al., 2010). Arsenic mobility and solubility in anion-fixing soils or alkaline soils can be strongly affected in case of high P supply (Smith et al., 1998; Violante and Pigna, 2002). As(V) and Pi adsorption-desorption had the similar characteristics and followed the Langmuir and Freundlich equations in the low $\mathrm{pH}$ (acid), neutral and high pH soils (calcareous purple soils) (Zou et al., 2009), but they are not always dependent on each other due to dissolution and mobility of un-reactive $\mathrm{P}$ at low $\mathrm{pH}$ (Mwamila and Gustafsson, 2011).

\section{As-Pi interaction, uptake and arsenic toxicity in plants}

\subsection{Mechanisms of As toxicity to plants}

The predominant effect of As toxicity in the cell is oxidative stress (Finnegan and Chen, 2012) that reduces seed germination, root and shoot growth and root surface area, etc. (Smith et al., 2010), restrict nutrients and water uptake, and cause nutrient deficiency in plants (Paivoke and Simola, 2001). After reduction arsenic (As(III) forms chemical bond with sulphydryl groups and deactivates some enzymes (Delnomdedieu et al., 1993), and increases reactive oxygen species and lipid peroxidation, but decreases the superoxide dismutase activity and antioxidants levels (Raab et al., 2004) resulting in cellular membrane damage (Mascher et al., 2002; Tuan et al., 2008). In contrast, Pi supply to As-treated plants decreased 
activities of CAT, APX and lipid peroxidation, and thus decreased membrane damage (Gunes et al., 2009). Arsenate in the cytoplasm competes with Pi forming unstable ADP-As(V), and disrupt the energy flows in cells (Hartley-Whitaker et al., 2001, 2002). High S concentrations in soil (e.g., via micronutrient fertilizers) alleviated the toxicity effect of As on plant growth although Pi addition to soil enhanced As uptake by plants (Grifoni et al., 2015). This phenomenon occurred due to formation of glutathione and phytochelatins, their chelation with As and subsequent sequestration of these chelated complexes in the vacuoles (Cobbett, 2000; Hartley-Whitaker et al., 2001). Although Pi supply suppressed the As uptake by plants in the hydroponics, high S addition increased As uptake and decreased Pi content influencing the As-Pi interaction in plants. Application of $\mathrm{As}$ and $\mathrm{Zn}$ to soils shows an antagonistic relationship such as $\mathrm{Zn}$ in soils (at application rate of $3 \mathrm{mg} / \mathrm{L}$ ) reduced As availability in soils and uptake in plants (Sanchary and Huq, 2017). Arsenic accumulation by plants is controlled by the oxidation state, As and $\mathrm{P}$ forms and plant species.

Arsenic hyperaccumulator plant species (e,g, Pteris vittata) detoxify As toxicity in a number of ways such as transformation of $\mathrm{As}(\mathrm{V})$ to $\mathrm{As}(\mathrm{III})$ by enzyme and compartmentalization in subcell; capturing reactive oxygen species by phytochelatin and thiols, preventing lipid peroxidation (Shoji et al., 2008; Bona et al., 2011) and maintaining a greater ratio of P/As in the roots, at least 1.2 in soil solution or 1.0 in fronds $(\mathrm{Tu}$ and $\mathrm{Ma}$, 2003a; Singh and Ma, 2006). Therefore, Pi application may be an important strategy for As detoxification, enhanced growth of Pteris vittata and efficient As uptake to phytoremediate As-contaminated soils (Kertulis et al., 2005; Ye et al., 2011; Yan et al., 2012). The in-situ measurement of As/Pi molar concentration ratio can predict As phytotoxicity, where As/Pi ratio of $0.168-0.360$ resulted in a $50 \%$ reduction of wheat (Triticum aestivum) growth (Mojsilovic et al., 2011). 


\subsection{As-Pi interactions and uptake by plants grown in soils}

The competition between $\mathrm{As}$ and $\mathrm{Pi}$, and the effect on their uptake by plants grown in soils are described briefly in Table 1 . Arsenate uptake from soil occurs via the same transport system as Pi (Pickering et al., 2000), however, the effects of As on plant metabolism are complex and only partially understood. An application of Pi had variable effects on the sorption and mobility of As in soils, uptake by plants and toxicity effects with both increases (Lambkin and Alloway, 2003; for $10 \mathrm{mg} \mathrm{P/} \mathrm{kg} \mathrm{in} \mathrm{Geng} \mathrm{et} \mathrm{al.,} \mathrm{2005;} \mathrm{238.4-423.2} \mathrm{mg} \mathrm{As/kg}$ soil and 10.0 mM phosphate addition in Tao et al., 2006) and decreases (Hanada et al., 1975; for $40 \mathrm{mg}$ P/ kg in Geng et al., 2005; Pigna et al., 2012) reported. Nevertheless, increasing Pi concentration could not resist a fraction of 'steady state' As(V) uptake, while As(V), in contrast, can inhibit 'steady state' Pi uptake mildly (Geng et al., 2005). Therefore, the interaction of As and $\mathrm{Pi}$, and suppressive effect of one on another is not straight forward. It is not yet studied how As interacts with organic P in soil. Irrigating As-rich water may change the As-Pi balance in soil solution, causing mobilisation of $\mathrm{Pi}$ and subsequent losses by leaching or higher Pi availability for plant nutrition. But higher As toxicity can affect crop yields as well (Talukder et al., 2011, 2012). The mobility of As and Pi, and As toxicity decreases due to formation of recalcitrant forms in aged soil (Onken and Adriano, 1997; Lombi et al., 1999).

The soil Pi status was related to As uptake by Urtica dioica, but not by Phragmites australis indicating a differential response of plants to Pi (Ahmed et al., 2011). The uptake kinetics of As and Pi by different plant species over short or long time vary depending on the genus and species of plants. Therefore, further research is necessary to understand a timecourse of $\mathrm{Pi}$ and $\mathrm{As}(\mathrm{V})$ uptake by different plant species. Compared to non-tolerant Holcus lanatus, the tolerant clones generally contained a higher proportion of As(V) (Quaghebeur and Rengel, 2003). Arsenic uptake by and growth of rice cutgrass (Leersia oryzoides Sw.) and 
tall fescue (Festuca arundinacea Schreb.) was not enhanced by $\mathrm{P}$ fertilization above a minimal amount (Klaber and Barker, 2014). The application of $\mathrm{Fe}^{2+}$ to the rice fields under flooded and reduced condition decreased the As uptake in rice grain and increased their yield, while Pi application demonstrated the opposite results (Hossain et al., 2009).

\subsection{Impact of Pi availability on As uptake by plants in hydroponics}

Phosphate and $\mathrm{As}(\mathrm{V})$ interactions in hydroponics and plant accumulation are largely investigated (Khattak et al., 1991; Clark et al., 2000; Pickering et al., 2000; Esteban et al., 2003; Panuccio et al., 2012; Shaibur et al., 2013) and briefly summarized in Table 2 and Fig. 1. Most studies found that Pi deficiency in nutrient solutions increased the capacity of rice and Lemma gibba plants to take up more $\mathrm{Pi}$ and $\mathrm{As}(\mathrm{V})$, but at low As concentration, high $\mathrm{Pi}$ treatment decreased $\mathrm{As}(\mathrm{V})$ uptake and toxicity (Macnair and Cumbes, 1987; Mkandawire et al., 2004; Lihong and Guilan, 2009; Panuccio et al., 2012) via suppression of the high-affinity $\mathrm{Pi} / \mathrm{As}(\mathrm{V})$ transport system. The supply of Pi also influenced the As speciation and transport (Lei et al., 2012). The Isatis cappadocica, a robust perennial rosette plant, can grow in highly impacted As-contaminated areas and hyperaccumulates As in its areal parts in hydroponic media (Karimi and Souri, 2015).

Phosphate can suppress As(V) uptake in phytoplankton (Planas and Healey, 1978), Oryza sativa (Abedin et al., 2002), Lupinus albus (Esteban et al., 2003), barley (Shaibur et al., 2013) and As-tolerant species such as Holcus lanatus, Cytisus striatus (Meharg and MacNair, 1992; Bleeker et al., 2003) and Pteris vittata (Wang et al., 2002; Tu and Ma, 2003b) grown in hydroponic systems. The time-dependent split-Pi application ( $\mathrm{P}_{134+66}$ and $\left.\mathrm{P}_{66+134}\right)$ with low initial Pi application increased the growth of Pteris vittata $\mathrm{L}$. and the efficiency of As removal, that was higher than high initial Pi-supply $\left(\mathrm{P}_{200+0}\right)$ (Santos et al., 2008). The radial loss of $\mathrm{O}_{2}$ from aerenchyma structures converts the rice root surface into much more highly 
oxidized condition compared to the surrounding environment (Colmer, 2003) and forms $\mathrm{Fe}$ oxide plaques on the root surface (Taylor et al., 1984).

The As-Pi interactions and their uptake by plants produced different and often contradictory results depending on soil substrates and hydroponic conditions. The kinetics of $\mathrm{Pi}$ and As accumulation in plants in hydroponics is overestimated compared to soil experiments, because some processes such as water flow, redox potential, diffusion, adsorption/desorption and ion exchange by minerals (Fe, Mn and Al oxyhydroxides, clay minerals, sulfide minerals, etc.) and organic components are common in soil systems that control As and Pi solubility and mobility in soils (Bissen and Frimmel, 2003; Anawar et al., 2008), while these processes do not occur in hydroponics (Fitz and Wenzel, 2002). Hence, the results from the hydroponic experiments can not be extrapolated to and may have limited validity for soil-grown plants (Fitz and Wenzel, 2002). However, the hydroponics studies can provide new knowledge on the membrane transport.

\subsection{Relation of plant P status with As uptake}

Quaghebeur and Rengel (2004) showed that P level in plant and As-Pi interactions in soil are pivotal factors controlling As and P uptake by plants. The Pi deficiency can enhance As uptake by plants e.g., Pteris vittata (Lei et al., 2012), P-deficient canola (Quaghebeur and Rengel, 2004) and white lupin (Lupinus albus) (Esteban et al., 2003), causing a decline in plant growth (Wang et al., 2002; Geng et al., 2006) except Pteris vittata. The low As uptake and amelioration of $\mathrm{As}(\mathrm{V})$ toxicity in most of the $+\mathrm{P}$ plants occurs by competition with $\mathrm{Pi}$ except lupin (Esteban et al., 2003; Reina et al., 2005). The P-deficient white lupin plants develop proteoid roots and take up more Pi and As(V) (Esteban et al., 2003; Reina et al., 2005), but lower translocation of As to shoot compared to corn plants (Vetterlein et al., 2009). The presence of $\mathrm{As}(\mathrm{V})$ stimulated $\mathrm{P}$ uptake by $\mathrm{P}$-deficient plants and reduced it for the $\mathrm{P}$ 
sufficient ones. However, the concentration of As in rice and barley shoots grown in hydroponics was very lower in P-deficient plants than in P-sufficient ones due to reddish iron plaque formed on the root surface sequestering As and decreasing its uptake by roots (Chen et al., 1980; Liu et al., 2004; Shaibur et al., 2013). Furthermore, it is assumed that high P level in As-tolerant plants could alleviate As toxicity more efficiently than non-tolerant ones, and despite the decreased $A s(V)$ uptake, As-tolerant plants might have higher total concentration of As in their biomass over long time (Campos et al., 2014).

Higher molar ratio of Pi/As in rice (Oryza sativa) shoots of Indica cultivar than for the hybrid Indica variety (Lu et al., 2010) suggested the genotypic difference in response to As $(\mathrm{V})$ toxicity and potential capacity to breed rice cultivars for As affected paddy soils (Geng et al., 2006).

\subsection{High-affinity and low-affinity Pi transporter for Pi and As uptake}

The different families of transporter proteins are involved in Pi transport through plant plasma membranes by a highly complex network of regulation, e.g., PHT1 transporters for Pi accumulation from soil (Nussaume et al., 2011). Plants have developed different controlled adaptative mechanisms to acquire necessary amount of external $\mathrm{Pi}$ and maintain $\mathrm{Pi}$ homeostasis as well as overcome low Pi availability (reviewed in Schachtman et al., 1998; Rouached et al., 2010). In the low Pi environment, Pi and $\mathrm{As}(\mathrm{V})$ accumulation by plants are controlled by the Pht1;9 and Pht1;8 membrane transporters through activation of high-affinity Pi transport system (Rausch and Bucher, 2002; Remy et al., 2012). Arsenate inhibited the root growth of non-tolerant Holcus lanatus plants more strongly than the tolerant genotypes. The tolerant plants (e.g., Holcus lanatus, Silene vulgaris and Agrostis species) took up less As(V) than non-tolerant ones over short time (Porter and Peterson, 1977; Zhao et al., 2009) supporting the hypothesis that a suppressed high-affinity Pi transport system provides As 
resistance together with increased $\mathrm{Pi} / \mathrm{As}$ ratio and strong selectivity against $\mathrm{As}(\mathrm{V})$ (Macnair and Cumbes, 1987). However, total As accumulation is higher in tolerant than non-tolerant plants over long time, as the latter become unhealthy and die relatively quickly (Puckett et al., 2012).

As(V) and Pi compete for transporters across root plasma membrane (Smith et al., 2010). Recently, Panuccio et al. (2012) indicated that As(V) resistance of Pennisetum clandestinum Hochst (kikuyu perennial grass) occurs due to enhanced Pi nutrition, and not due to downregulation of the Pi uptake system. Aquaglyceroporins (AQP3, AQP7, AQP9, and AQP10) mediate the bidirectional movement of arsenite across cell membranes (Jung et al., 2012). The As(III) transport was not affected by Pi in rice.

\subsection{Effect of root exudates on As and Pi uptake}

The plant root exudates play critical roles in As and Pi release from soil matrix. The main factors controlling the mobility of As in surrounding environment of roots and uptake by plants include solubilisation of As from the soil matrix/minerals, very large surface areas of roots (Pollard et al., 2002), rhizosphere $\mathrm{pH}$, and chelating agent (Quaghebeur et al., 2005; Marschner, 1995). The root exudates including organic acids and phenolics released by the Pdeficient plants can mobilize $\mathrm{Pi}$ and As from soil matrix including Fe-oxides/hydroxides, and enhance availability to plants by changing soil $\mathrm{pH}$ and through forming soluble metal-chelate complexes (Hoffland, 1992; Strom et al., 1994; Kirk et al., 1999).

\subsection{Does As resistance occur via decreased As uptake or protective effect of high Pi uptake?}

Arsenic tolerance in higher plants hinges on decreased As accumulation by suppression of the high-affinity Pi/As(V) uptake system in roots (Meharg and Macnair, 1992) and decreased As transport to shoots (Pigna et al., 2009), both of which are dependent on high shoot Pi 
status that outcompetes As in metabolic reactions as reported for the arsl Arabidopsis mutants (Lee et al., 2003) and vacuolar sequestration of As in shoots. However, our data analysis from Pigna et al. (2009, 2010) and Lewinska and Karczewska (2013) demonstrate the new results as follows: Pi application to soils not only augmented plant growth, but also increased As and Pi concentrations in shoot of wheat (Triticum durum L.) irrigated with Asrich water (Fig. 2). Therefore, it is clear that Pi addition to soils alleviated As toxicity not by decreasing As uptake by plants, but increasing the plant biomass, Pi nutrition and metabolic reactions. Joardar and Kawai (2014) and Christophersen et al. (2009a) also reported that the decreased As toxicity occurred not due to lower As uptake by plants, but increased Pi uptake by plant root surface and transport to shoot (Campos et al., 2014). A more detailed investigation of uptake of $\mathrm{As}(\mathrm{V})$ and $\mathrm{Pi}$ is necessary to clarify this hypothesis. Our recent study indicated that $\mathrm{P}$ addition to topsoil (upper $5 \mathrm{~cm}$ ) of three-layered soil system with As in the subsoil $(>10 \mathrm{~cm})$ was a more effective strategy to impove the plant growth by alleviating As toxicity, increasing $\mathrm{P}$ concentration, but reducing As level in plant biomass than $\mathrm{P}$ application in subsoil (Anawar et al., 2016).

\section{Role of mycorrhiza on As-P interaction in soil system and uptake by plant}

The symbiotic association of arbuscular mycorrhizal (AM) fungi with plant roots growing in As-contaminated soil has been demonstrated to improve $\mathrm{P}$ nutrition, reduce As(V) uptake, increase P/As ratios in the shoots, and alleviate As toxicity for several plant species (Fig. 3) (Meharg et al., 1994; Chen et al., 2007; Ultra et al., 2007; Xia et al., 2007; Xu et al., 2008; Christophersen et al., 2009b, 2012; Ahmed et al., 2006, 2011). Albeit some studies did not demonstrate good responses to AM fungi for tolerance to soil As (Knudson et al., 2003; Zhu et al., 2003; Li et al., 2006; Grace et al., 2009), indicating that the benefits of the AM association may not be universal for all scenarios (e.g., basin wildrye). 
Based on demonstrated studies it is reported that AM plant roots may have physiologically altered Pi uptake systems, whereby there is a switch from the epidermal uptake pathway to an AM uptake pathway following colonisation. Considering the physiological and molecular evidence, Smith et al. (2003) showed that AM plants have two pathways for Pi and As(V) uptake: direct pathway via high-affinity Pi transporters Pht1;1 and Pht1;2 in the epidermis and root hairs in AM and NM (non-mycorrhizal) plants (Schunmann et al., 2004a,b; Shin et al., 2004) regardless of their responsiveness (Smith et al., 2010). The down-regulation of expression of high-affinity Pi-uptake pathway lowered Pi and As(V) uptake in AM barley and genotypes of As-tolerant Holcus lanatus, but other studies indicated no such effect (Grace et al., 2009). However, it suggested that the AM and direct Pi uptake pathways are integrated, and Pi and As(V) uptake may be inter-dependent (Smith et al., 2003, 2004; Smith and Read, 2008), although details of the mechanisms are still unclear.

The transporters in external hyphae of the AM fungi in symbiosis condition uptake Pi via the mycorrhizal pathway (Maldonado-Mendoza et al., 2002). The hyphae transports Pi along a long way (Ezawa et al., 2002) and transfer to plant across a symbiotic interface to cortical cells by induction of Pht1;8 in roots (Paszkowski et al., 2002; Glassop et al., 2005). Thus, a higher amount of Pi and exclusion of As are promoted by the AM pathway that protect plants against As uptake and toxicity (Christophersen et al., 2009b). It suggested that AMF decreased As toxicity in soil by converting As speciation from inorganic to organic forms by hyphae-produced glomalin (Ultra Jr et al., 2007; Chern et al., 2007; Smith and Read, 2008) and acting as a barrier for As uptake (Ultra Jr et al., 2007; Ahmed et al., 2011) through several physical mechanisms: adsorption onto plant or fungal cell walls in plant tissues or extraradical mycelium in soil (Hildebrandt et al., 1999; Kaldorf et al., 1999; Joner et al., 2000); exclusion by precipitation onto polyphosphate granules (Turnau et al., 1993). Some studies reported that lower As uptake in shoot occurred mainly due to a "dilution effect" from 
increased growth of AM plants and decreased As partitioning to shoots, rather than decreased As uptake per plant (Chen et al., 2007; Zhao et al., 2009; Ahmed et al., 2011). Therefore, further research is needed to determine the effects of AM fungi-induced various metabolic strategies for As resistance mechanism and As uptake by plants. A recent study suggests that mycorrhizal colonization converts As into non-toxic compexes by enhancing the production of cysteine, glutathione, non-protein thiols, and activity of glutathione-S-transferase in plants indicating the multifarious role of AMF in alleviation of As toxicity (Sharma et al., 2017). Furthermore, Pi from superphosphate fertilizer or other sources may suppress the AMF colonization, change the structure of the AMF community (Shetty et al., 1995; Ahmed et al., 2011) and thus strongly influence any potential AM effect on As resistance. Combined application of inoculum and Pi to soil augmented plant biomass, reduced As toxicity and increased plant Pi nutrition; and these effects were higher than inoculation only with native AMF (Cozzolino et al., 2010; Cattani et al., 2015).

Glomus mosseae that was more tolerant and unaffected by the high concentrations of As (e.g., $200 \mathrm{mg} / \mathrm{kg}$ ) than Medicago truncatula plant, increased host plant As tolerance and Pi nutrition (Xu et al., 2008). Not only AMF, but also ericoid and ectomycorrhizal fungi can increase their tolerance to $\mathrm{As}(\mathrm{V})$ contamination via different mechanisms (Sharples et al., 1999, 2000a). The ericoid mycorrhizal fungus Hymenoscyphus ericae from an As and $\mathrm{Cu}$ mine spoil has adapted to As(V) contamination by decreasing As uptake via enhanced As(III) efflux (Sharples et al., 2000b), but the mechanisms behind this process are still unclear. Three species of ectomycorrhizal fungi showed variable response to arsenate toxicity under the influence of $\mathrm{PO}_{4}{ }^{3-}$ concentration (Chen and Tibbett, 2007). The Suillus variegatus and Hebeloma crustuliniforme exhibited the high sensitivity to As toxicity at low Pi treatments, while the higher Pi treatments reduced As toxicity. In contrast, the Cenococcum 
geophilum exhibited higher tolerance to As; and Pi did not show ameliorating effect on As toxicity in C. geophilum.

\section{Influence of soil microbial communities on As and Pi uptake by plants}

Microbial activity causes transformation of As sepcies by reduction (arsenate to arsenite), oxidation (arsenite to arsenate), and methylation (Wang et al., 2004; Qin et al., 2006; Cai et al., 2009). Arsenic reduces the soil functional gene diversity, while Pi increases the soil microbial community structure. The rhizobacteria accelerate As hyperaccumulation by $P$. vittata (Xiong et al., 2010), even under a Pi-limiting environment (e.g., insoluble phosphate rock in alkaline soil) in As-rich media (Lessl and Ma, 2013; Lessl et al., 2014). By excreting acids, protons, and siderophores, the rhizobacteria can cause dissolution of phosphate rock and minerals that improve plant Pi nutrition and As uptake by plants (Duponnois et al., 2005; Ghosh et al., 2015). Due to the continuous excretion of plant released organic substrates, the number of microorganisms in the rhizosphere increases compared to the non-rhizosphere soil resulting in a more diverse bacterial community (Marschner, 1995). Microbial reduction of As(V) to As(III) occurs by dissimilatory reduction and detoxification activities of microbes (Fitz and Wenzel, 2002) using $\mathrm{As}(\mathrm{V})$ as a terminal electron acceptor, and also As(V) reductase and As(III) extrusion by an As(III)-efflux pump (Cervantes et al., 1994).

\section{Conclusions}

The soil type, structure, properties, mineral components and $\mathrm{pH}$ may greatly affect the AsPi interactions, mobility and availability of As in soils and uptake by plants with increased As availability and toxicity on sandy soil, but lower on a silty and sandy clay loam soils. Although all hydroponic studies indicated that Pi additions decreased As uptake by plant resulting in mitigating As toxicity, Pi application to soil either increased or decreased As 
uptake and toxicity effects by tolerant and non-tolerant plants depending on substrate conditions. What is the main reason behind these processes is not yet explained in any study. Therefore, this review hypothesized these processes as follows. The concentration of both Pi and $\operatorname{As}(\mathrm{V})$ in soil solution is typically orders of magnitude lower than the concentrations employed in the majority of hydroponic studies. For example, Wenzel et al. (2002) reported As(V) concentrations in the soil solutions from a range of uncontaminated and moderately contaminated soils to be $\leq 53 \mathrm{nM}$ and up to $2.3 \mu \mathrm{M}$ in a highly contaminated soil. Similarly, Pi concentrations in soil solution are typically $<10 \mu \mathrm{M}$ (Bieleski, 1973), which again is orders of magnitude lower than the range of Pi concentrations employed in hydroponic experiments (e.g., Tu and Ma, 2003b, 202-1000 $\mu \mathrm{M}$; Clark et al., 2000, 10-250 $\mu \mathrm{M}$; Meharg et al., 1994, 25-1000 $\mu \mathrm{M}$ ). Unrealistically high concentrations of Pi may elicit (low affinity) uptake pathways and metabolic processes which are not reflected in soil culture. Therefore, further hydroponic studies are recommended using the As and Pi concentrations that are commonly available in soil porewater.

In soils, Pi additions generally result in increased Pi and As uptake, and also increased As resistance indicating that increased levels of Pi in plant biomass reduced the toxicity effects of As. The effects of $\mathrm{As}(\mathrm{V})$ on Pi uptake are relatively weak due to high affinity of the transporters for Pi than $\mathrm{As}(\mathrm{V})$ in both hydroponics and soils. At low $\mathrm{As}(\mathrm{V})$ concentration, a high-Pi treatment decreased uptake and toxicity of $\mathrm{As}(\mathrm{V})$ in non-tolerants but not in Astolerant plants. The As-tolerant plants might have distinct Pi uptake system with high selectivity for $\mathrm{Pi}$ and against $\mathrm{As}(\mathrm{V})$ resulting in higher $\mathrm{Pi} / \mathrm{As}$ ratio and As resistance. New data analysis indicates that $\mathrm{Pi}$ addition promoted plant growth and As resistance not by reducing As uptake by plants, but increasing Pi concentrations in shoot and protective activity by internal P-induced metabolic reactions. Sulphur in soil can enhance As uptake by plants due to its ability to reduce the toxicity effects. The mycorrhizal association contributes to the 
increased Pi nutrition, plant growth and in ameliorating As toxicity. Microorganisms in the rhizosphere can cause transformation of As sepcies by redox reactions and methylation. The rhizobacteria release different types of acids to cause the dissolution of phosphate rock and minerals resulting in higher Pi nutrition and As uptake by plants.

\section{Recommendations for future work}

The previous studies related to As-Pi interactions in different substrates and the role of soil types on $\mathrm{Pi}$ and $\mathrm{As}(\mathrm{V})$ mobility and uptake by plants produced the contradictory results. Although the results from all hydroponic studies demonstrated the similar results, the studies conducted on soils showed a lot of discrepancies. Therefore, further research works are highly recommended to study the As-Pi interactions and uptake by plants grown in different soil types. After Pi addition to soil, higher Pi uptake and translocation from root to shoot can contribute to more resistance to As toxicity to plants than decreased As uptake. However, more detailed study is required to have a clear idea about how uptake of Pi ameliorates the As toxicity to plants. Several mechanisms for amelioration of As toxicity by AMF have been proposed and discussed in this review, and further research is needed to characterize these mechanisms, particularly a lack of As transport and increased Pi uptake via the AM pathway in plants. Since high Pi supply decreases mycorrhizal colonisation, proper management of Pi fertilization can increase the efficiency of mycorrhizae for enhanced Pi and a decreased As uptake. Therefore, this hypothesis should be further investigated in areas where --high As concentrations may exist in agricultural soils, irrigation water and/or groundwater. Using the isotopes can help to reveal these mechanisms as well.

\section{Acknowledgements}


This study received the financial support from the Australian Research Council Linkage

474

475

476

477

478

479

480

481

482

483

484

485

486

487

488

489

490

491

492

493

494

495

496

497

498

499

500

501

502

503

504

project (LP110200961).

\section{References}

Abedin, M.J., Feldmann, J., Meharg, A.A., 2002. Uptake kinetics of arsenic species in rice plants. Plant Physiology 128, 1120-1128.

Ahmed, F.R.S., Killham, K., Alexander, I., 2006. Influences of arbuscular mycorrhizal fungus Glomus mosseae on growth and nutrition of lentil irrigated with arsenic contaminated water. Plant and Soil 283, 33-41.

Ahmed, F.R.S., Alexander, I.J., Mwinyihija, M., Killham, K., 2011. Effect of superphosphate and arbuscular mycorrhizal fungus Glomus mosseae on phosphorus and arsenic uptake in lentil (Lens culinaris L.). Water Air Soil Pollution 221, 169-182.

Anawar, H.M., Akai, J., Mostofa, K.M.G., Safiullah, S., Tareq, S.M., 2002. Arsenic poisoning in groundwater: health risk and geochemical sources in Bangladesh. Environment International 27, 597-604.

Anawar, H.M., Garcia-Sanchez, A., Santa-Regina, I., 2008. Evaluation of various chemical extraction methods to estimate plant-available arsenic in mine soils. Chemosphere 70, 1459-1467.

Anawar, H.M., Akai, J., Mihaljevič, M., Sikder, A.M., Ahmed, G., Tareq, S.M., Rahman, M.M., 2011. Arsenic contamination in groundwater of Bangladesh: perspectives on geochemical, microbial and anthropogenic issues. Water 3, 1050-1076.

Anawar, H.M., Damon, P., Rengel, Z., Jasper, D.A., Tibbett, M., 2016. Alleviating arsenic toxicity to plants in a simulated cover system with phosphate placement in topsoil and subsoil. In: AB Fourie \& M Tibbett (eds), Proceedings of the 11th International Conference on Mine Closure, Australian Centre for Geomechanics, Perth, pp. 555-565.

Asher, C.J., Reay, P.F., 1979. Arsenic uptake by barIey seedlings. Austealian Journal of Plant Physiology 6, 459-466.

ATSDR (Agency for Toxic Substances and Disease Registry), 2007. Toxicological profile for arsenic. Atlanta, GA: U.S. Department of Health and Human Services, Public Health Service.

Bieleski, R.L., 1973. Phosphate pools, phosphate transport, and phosphate availability. Annual Review in Plant Physiology 24, 225-252. 
Bissen, M., Frimmel, F.H., 2003. Arsenic - a review. Part I: Occurrence, toxicity, speciation, mobility. Acta hydrochim. Hydrobiology 31(1), 9-18.

Bleeker, P.M., Schat, H., Vooijs, R., Verkleij, J.A.C., Ernst, W.H.O., 2003. Mechanisms of arsenate resistance in Cytisus striatus. New Phytology 157, 33-38.

Bolan, N., Mahimairaja, S., Kunhikrishnan, A., Choppala, G., 2013. Phosphorus-arsenic interactions in variable-charge soils in relation to arsenic mobility and bioavailability. Science of the Total Environment 463-464, 1154-1162.

Bona, E., Marsano, F., Massa, N., Cattaneo, C., Cesaro, P., Argese, E., Toppi, L.S., Cavalett, M., Berta, G., 2011. Proteomic analysis as a tool for investigating arsenic stress in Pteris vittata roots colonized or not by arbuscular mycorrhizal symbiosis. Journal of Proteomics $74,1338-1350$.

Bowen, H.J.M., 1979. Environmental Chemistry of the Elements. Academic Press, London.

Cai, L., Liu, G., Rensing, C., Wang, G., 2009. Genes involved in arsenic transformation and resistance associated with different levels of arsenic-contaminated soils. BMC Microbiology 9, 4.

Campos, N.V., Loureiro, M.E., Azevedo, A.A., 2014. Differences in phosphorus translocation contributes to differential arsenic tolerance between plants of Borreria verticillata (Rubiaceae) from mine and non-mine sites. Environmental Science and Pollution Research 21, 5586-5596.

Cao, X., Ma, L.Q., 2004. Effects of compost and phosphate on plant arsenic accumulation from soils near pressure treated wood. Environmental Pollution 132, 435-442.

Cattani, I., Beone, G.M., Gonnelli, C., 2015. Influence of Rhizophagus irregularis inoculation and phosphorus application on growth and arsenic accumulation in maize (Zea mays L.) cultivated on an arsenic-contaminated soil. Environmental Science and Pollution Research $22,6570-6577$.

Chen, B., Xiao, X., Zhu, Y.-G., Smith, F.A., Xie, Z.M., Smith, S.E., 2007. The arbuscular mycorrhizal fungus Glomus mosseae gives contradictory effects on phosphorus and arsenic acquisition by Medicago sativa Linn. Science of the Total Environment 379, 226-234.

Chen, S.H., Tibbett, M., 2007. Phosphate supply and arsenate toxicity in ectomycorrhizal fungi. Journal of Basic Microbiology 47, 358-362.

Chen, C.C., Dixon, J.B., Turner, F.T., 1980. Iron coating on rice root: morphology and model of development. Soil Science Society of America Journal 44, 1113-1119. 
Chern, E.C., Tsai, D.W., Ogunseitan, O.A., 2007. Deposition of glomalin-related soil protein and sequestered toxic metals into watersheds. Environmental Science and Technology 41, $3566-3572$.

Christophersen, H.M., Smith, S.E., Pope, S., Smith, F.A., 2009a. No evidence for competition between $\mathrm{As}(\mathrm{V})$ and phosphate for uptake from soil by medic or barley. Environment International 35, 485-490.

Christophersen, H.M., Smith, F.A., Smith S.E., 2009b. Arbuscular mycorrhizal colonization reduces $\mathrm{As}(\mathrm{V})$ uptake in barley via downregulation of transporters in the direct epidermal phosphate uptake pathway. New Phytologist 184, 962-974.

Clark, G.T., Dunlop, J., Phung, H.T., 2000. Phosphate absorption by Arabidopsis thaliana: interactions between phosphorus status and inhibition by arsenate. Australian Journal of Plant Physiology 27, 959-965.

Cobbett, C.S., 2000. Phytochelatins and their roles in heavy metal detoxification. Plant Physiology 123, 825-832.

Colmer, T.D., 2003. Long-distance transport of gases in plants: a perspective on internal aeration and radial oxygen loss from roots. Plant Cell Environment 26, 17-36.

Cozzolino, V., Pigna, M., Di Meo, V., Caporale, A.G., Violante, A., 2010. Effects of arbuscular mycorrhizal inoculation and supply on the growth of Lactuca sativa L. and arsenic and phosphorus availability in an arsenic polluted soil under non-sterile conditions. Applied and Soil Ecology 45, 262-268.

Creger, T., Peryea, F., 1994. Phosphate fertilizer enhances arsenic uptake by apricot liners grown in lead-As(V)-enriched soil. Horticulture Science 29, 88-92.

Dalal, R.C., 1977. Soil organic phosphorus. Advances in Agronomy 29, 85-117.

Delnomdedieu, M., Basti, M.M., Otvos, J.D., Thomas, D.J., 1993. Transfer of As(III) from glutathione to dithiols: A model of interaction. Chemical Research and Toxicology 6, 598602.

Dunlop, J., Phung, H.T., Meeking, R., White, D.W.R., 1997. The kinetics associated with phosphate absorption by Arabidopsis and its regulation by phosphorus status. Australian Journal of Plant Physiology 24, 623-629.

Duponnois, R., Colombet, A., Hien, V., Thioulouse, J., 2005. The mycorrhizal fungus Glomus intraradices and rock phosphate amendment influence plant growth and microbial activity in the rhizosphere of Acacia holosericea. Soil Biology and Biochemistry 37, 1460-1468. 
Esteban, E., Carpena, R.O., Meharg, A.A., 2003. High-affinity phosphate/As(V) transport in white lupin (Lupinus albus) is relatively insensitive to phosphate status. New Phytologist $158,165-173$.

Ezawa, T., Smith, S.E., Smith, F.A., 2002. P metabolism and transport in AM fungi. Plant and Soil 244, 221-230.

Fitz, W.J., Wenzel, W.W., 2002. Arsenic transformations in the soil-rhizosphere-plant system: fundamentals and potential application to phytoremediation. Journal of Biotechnology 99, 259-278.

Finnegan, P.M., Chen, W., 2012. Arsenic toxicity: the effects on plant metabolism. Frontier in Physiology 3, 182.

Fordham, A.W., Norrish, K., 1979. Arsenate-73 uptake by components of several acidic soils and its implications for phosphate retention. Australian Journal of Soil Research 17, 307316.

Geng, C.N., Zhu, Y.G., Tong, Y.P., Christie, P., 2005. Uptake and translocation of arsenic and phosphorus in pho2 mutant and wild type of Arabidopsis thaliana. Journal of Plant Nutrition 28, 1323-1336.

Geng, C.N., Zhu, Y.G., Hu, Y., Williams, P., Meharg, A.A., 2006. Arsenate causes differential acute toxicity to two P-deprived genotypes of rice seedlings (Oryza sativa L.). Plant and Soil 279, 297-306.

Ghosh, P., Rathinasabapathi, B., Ma, L.Q., 2015. Phosphorus solubilization and plant growth enhancement by arsenic-resistant bacteria. Chemosphere 134, 1-6.

Glassop, D., Smith, S.E., Smith, F.W., 2005. Cereal phosphate transporters associated with the mycorrhizal pathway of phosphate uptake into roots. Planta 222, 688-698.

Grace, E.J., Cotsaftis, O., Smith, F.A. et al., 2009. Arbuscular mycorrhizal inhibition of growth in barley cannot be attributed to extent of colonisation, fungal $\mathrm{P}$ uptake or effects on plant phosphate transporter expression. New Phytologist 181, 938-949.

Grifoni M, Schiavon M, Pezzarossa B, Petruzzelli G, Malagoli M (2015) Effects of phosphate and thiosulphate on arsenic accumulation in the species Brassica juncea. Environmental Science and Pollution Research 22, 2423-2433.

Gunes, A., Pilbeam, D. J., Inal, A., 2009. Effect of arsenic-phosphorus interaction on arsenicinduced oxidative stress in chickpea plants. Plant and Soil 314, 211-220.

Hanada, S., Nakano, M., Saitoh, H., Mochizuki, T., 1975. Studies on the pollution of apple orchard surface soils and its improvement in relation to inorganic spray residues. I. Bulletin of Faculty of Agriculture, Hirosaki University 25, 13-17. 
Hartley-Whitaker, J., Ainsworth, G.C., Meharg, A.A., 2001. Copper-and arsenate-induced oxidative stress in Holcus lanatus L. clones with differential sensitivity. Plant Cell and Environment 24, 713-722.

Hartley-Whitaker, J., Woods, C., Meharg, A.A., 2002. Is differential phytochelatin production related to decreased arsenate influx in arsenate tolerant Holcus lanatus? New Phytologist $155,219-225$.

Hildebrandt, U., Kaldorf, M., Bothe, H., 1999. The zinc violet and its colonization by arbuscular mycorrhiza fungi. Journal of Plant Physiology 154, 709-717.

Hossain, M.B., Jahiruddin, M., Loeppert, R.H., Panaullah, G.M., Islam, M.R., Duxbury, J.M., 2009. The effects of iron plaque and phosphorus on yield and arsenic accumulation in rice. Plant and Soil 317, 167-176.

Huang, R.-Q., Gao, S.-F., Wang, W.-L., Staunton, S., Wang, G., 2006. Soil arsenic availability and the transfer of soil arsenic to crops in suburban areas in Fujian Province, southeast China. Science of the Total Environment 368, 531-541.

Jacobs, L.W., Keeney, D.R., 1970. Arsenic - phosphorus interactions on corn. Communications in Soil Science and Plant Analysis 1, 85-93.

Joardar J, Kawai S (2014) Phosphate rich soil additive baked pig manure effectively reduces arsenic concentration in Japanese mustard spinach (Brassica rapa var. perviridis) grown with arsenic contaminated irrigation water. American Journal of Expermental Agriculture 4, 142-152.

Joner, E.J., Briones, R., Leyval, C., 2000. Metal-binding capacity of arbuscular mycorrhizal mycelium. Plant and Soil 226, 227-234.

Jung, D., MacIver, B., Jackson, B.P., Barnaby, R., Sato, J.D., Zeidel, M.L., Shaw, J.R., Stanton, B.A., 2012. A novel aquaporin 3 in killifish (Fundulus heteroclitus) is not an arsenic channel. Toxicological Science 127, 101-109.

Jung, MC, Thornton I and Chon, H-T. 2002. Arsenic, Sb and Bi contamination of soils, plants, waters and sediments in the vicinity of the Dalsung $\mathrm{Cu}-\mathrm{W}$ mine in Korea. Sci Total Environ, 295, 81-89.

Kaldorf, M., Kuhn, A. J., Schroder, W. H., Hildebrandt, U., Bothe, H., 1999. Selective element deposits in maize colonized by a heavy metal resistance conferring arbuscular mycorrhizal fungus. Journal of Plant Physiology 154, 718-728.

Karimi, N., Souri, Z., 2015. Effect of phosphorus on arsenic accumulation and detoxification in arsenic hyperaccumulator, Isatis cappadocica. Journal of Plant Growth Regulation 34, 88-95. 
Kertulis, G.M., Ma, L.Q., MacDonald, G.E., Chen, R., Winefordner, J.D., Cai, Y., 2005. Arsenic speciation and transport in Pteris vittata L. and the effects on phosphorus in the xylem sap. Environmental and Experimental Botany 54, 239-247.

Khattak, R.A., Page, A.L., Parker, D.R., Bakhtar, D., 1991. Accumulation and interactions of arsenic, selenium, molybdenum and phosphorus in alfalfa. Journal of Environmental Quality 20, 165-168.

Klaber, N.S., Barker, A.V., 2014. Accumulation of phosphorus and arsenic in two perennial grasses for soil remediation. Communic Soil Science and Plant Analysis 45, 810-818.

Knudson, J.A., Meikle, T., DeLuca, T.H., 2003. Role of mycorrhizal fungi and phosphorus in the arsenic resistance of basin wildrye. Journal of Environmental Quality 32, 2001-2006.

Koo, N., Kim, M.-S., Hyun, S., Kim, J.-G., 2013. Effects of the incorporation of phosphorus and iron into arsenic-spiked artificial soils on root growth of lettuce using response surface methodology. Communications in Soil Science and Plant Analysis 44, 1259-1271.

Lambkin, D.C., Alloway, B.J., 2003. As(V) -inducedphosphate release from soils and its effect on plant phosphorus. Water, Air, and Soil Pollution 144, 41-56.

Lee, D.A., Chen, A., Schroeder, J.I., 2003. Ars1, an Arabidopsis mutant exhibiting increased resistanceto arsenate and increased phosphate uptake. Plant Journal 35, 637-646.

Lei, M., Wan, X.-M., Huang, Z.-C., Chen, T.-B., Li, X.-W., Liu, Y.-R., 2012. First evidence on different transportation modes of arsenic and phosphorus in arsenic hyperaccumulator Pteris vittata. Environmental Pollution 161, 1-7.

Lessl, J.T., Ma, L.Q., 2013. Sparingly-soluble phosphate rock induced significant plant growth and arsenic uptake by Pteris vittata from three contaminated soils. Environmental Science and Technology 47(10), 5311-5318.

Lessl, J.T., Luo, J., Ma, L.Q., 2014. Pteris vittata continuously removed arsenic from nonlabile fraction in three contaminated-soils during 3.5 years of phytoextraction. Journal of Hazardous Materials 279, 485-492.

Lewinska, K., Karczewska, A., 2013. Influence of soil properties and phosphate addition on arsenic uptake from polluted soils by velvet grass (Holcus lanatus). Internationa Journal of Phytoremediation 15, 91-104.

Li, H.Y., Smith, S.E., Holloway, R.E. et al., 2006. Arbuscular mycorrhizal fungi contribute to phosphorus uptake by wheat grown in a phosphorus-fixing soil even in the absence of positive growth responses. New Phytologist 172, 536-543. 
Li, R.-Y., Ago, Y., Liu, W.-J., Mitani, N., Feldmann, J., McGrath, S.P., Ma, J F., Zhao, F.-J., 2009. The rice aquaporin Lsi1 mediates uptake of methylated arsenic species. Plant Physiology 150, 2071-2080.

Lihong, W., Guilan, D., 2009. Effect of external and internal phosphate status on arsenic toxicity and accumulation in rice seedlings. Journal of Environmental Science 21, 346351.

Liu, W.-J., Zhu, Y.-G., Smith, F.A., Smith, S.E., 2004. Do phosphorus nutrition and iron plaque alter As(V) uptake by rice seedlings in hydroponic culture? New Phytologist 162, 481-488.

Lombi, E., Wenzel, W.W., Sletten, R., 1999. Arsenic adsorption by soil and iron-coated sand: kinetics and reversibility. Journal of Plant Nutrition and Soil Science 162, 451-456.

Lou, L., Ye, Z., Lin, A., Wong, M., 2010. Interaction of arsenic and phosphate on their uptake and accumulation in Chinese brake fern. International Journal of Phytoremediation 12, 487-502.

Lu, Y., Dong, F., Deacon, C., Chen, H.-J., Raab, A., Meharg, A.A., 2010. Arsenic accumulation and phosphorus status in two rice (Oryza sativa L.) cultivars surveyed from fields in South China. Environmental Pollution 158, 1536-1541.

Ma, J.F., Yamaji, N., Mitani, N., Xu, X.-Y., Su, Y.-H., McGrath, S.P., Zhao, F.-J., 2008. Transporters of arsenite in rice and their role in arsenic accumulation in rice grain. Proceedings of National Academy of Science, USA 105, 9931-9935.

Maldonado-Mendoza, I.E., Dewbre, G.R., van Buuren, M.L., Versaw, W., Harrison, M.J., 2002. Methods to estimate the proportion of plant and fungal RNA in an arbuscular mycorrhizal fungus. Mycorrhiza 12, 67-74.

Marschner, H., 1995, Mineral Nutrition of Higher Plants, 2nd ed., Academic Press, London, 889 pp.

Mascher, R., Lippmann, B., Holzinger, S. et al., 2002. Arsenate toxicity: effects on oxidative stress response molecules and enzymes in red clover plants. Plant Science 163, 961-969.

McBride, M.B., 1994. Environmental Chemistry of Soils, Oxford University Press, UK.

Meharg, A.A., MacNair, M.R., 1992. Suppression of the high affinity phosphate uptake system: A mechanism of As(V) resistance in Holcus lanatus L. Journal of Experimental. Botany 43, 519-524.

Meharg, A.A., Naylor, J., Macnair, M.R., 1994. Phosphorus nutrition of arsenate-tolerant and nontolerant phenotypes of velvet grass. Journal of Environmental Quality 23, 234-238. 
Meharg, A.A., Hartley-Whitaker, J., 2002. Arsenic uptake and metabolism in arsenic resistant and non resistant plant species. New Phytologist 154, 29-43.

Melamed, R., Jurinak, J.J., Dudley, L.M., 1995. Effect of adsorbed phosphate on transport of arsenate through an oxisol. Soil Science Society of America Journal 59, 1289-1294.

Milivojevic, D.B., Nikolicand, B.R., Drinic, G., 2006. Effects of arsenic on phosphorus content in different organs and chlorophyll fluorescence in primary leaves of soybean. Biologia Plantarum 50, 149-151.

Mkandawire, M., Lyubun, Y.V., Kosterin, P.V., Dudel, E.G., 2004. Toxicity of arsenic species to Lemna gibba L. and the influence of phosphate on arsenic bioavailability. Environmental Toxicology 19, 26-34.

Macnair, M.R., Cumbes, Q., 1987. Evidence that arsenic resistance in Holcus lanatus L. is caused by an altered phosphate uptake system. New Phytologist 107, 387-394.

Manning, B.A., Goldberg, S., 1996. Modeling competitive adsorption of As(V) with phosphate and molybdate on oxide minerals. Soil Science Society of America Journal 60, 121-131.

Mojsilovic, O., McLaren, R.G., Condron, L.M., 2011. Modelling arsenic toxicity in wheat: Simultaneous application of diffusive gradients in thin films to arsenic and phosphorus in soil. Environmental Pollution 159 (10), 2996-3002.

Mwamila L, Gustafsson JP (2011) Arsenic (V) and phosphate sorption to Swedish clay soils Freundlich sorption modelling, KTH, Skolan för arkitektur och samhällsbyggnad (ABE), Mark- och vattenteknik (flyttat 20130630), Miljögeokemi och ekoteknik.

Nagy, F., Karandashov, V., Chague, W. et al., 2005. The characterization of novel mycorrhiza-specific phosphate transporters from Lycopersicon esculentum and Solanum tuberosum uncovers functional redundancy in symbiotic phosphate transport in solanaceous species. Plant Journal 42, 236-250.

Nussaume, L., Kanno, S., Javot, H., Marin, E., Pochon, N., Ayadi, A., Nakanishi, T.M., Thibaud, M.-C., 2011. Phosphate import in plants: focus on the PHT1 transporters. Frontiers in Plant Science 2, 1-12.

O’Neill, 1992. Heavy metals in soils. Alloway, B.J (Ed.), $2^{\text {nd }}$ Edition, Blackie Academic \& Professional, London, UK, pp. 105-121.

Onken BM, Adriano DC (1997) Arsenic availability in soil with time under saturated and subsaturated conditions. Soil Science Society of America Journal 61, 746-751. 
Paivoke, A.E.A., Simola, L.K., 2001. Arsenate toxicity to Pisum sativum: mineral nutrients, chlorophyll content and phytase activity. Ecotoxicology and Environmental Safety 49, $111-121$.

Pantsar-Kallio, M., Manninen, P.K.G., 1997. Speciation of mobile arsenic in soil samples as a function of pH. Science of the Total Environment 204, 193-200.

Panuccio, M.R., Logoteta, B., Beone, G.M., Cagnin, M., Cacco, G., 2012. Arsenic uptake and speciation and the effects of phosphate nutrition in hydroponically grown kikuyu grass (Pennisetum clandestinum Hochst). Environmental Science and Pollution Research 19, 3046-3053.

Paszkowski, U., Kroken, S., Roux, C. et al. 2002. Rice phosphate transporters include an evolutionarily divergent gene specifically activated in arbuscular mycorrhizal symbiosis. Proceedings of National Academy of Science, USA 99, 13324-13329.

Peryea, F. J., 1991. Phosphate-induced release of arsenic from soils contaminated with lead arsenate. Soil Science Society of America Journal 55, 1301-1306.

Peryea, F.J., 1998. Phosphate starter fertilizer temporarily enhances soil arsenic uptake by apple trees grown under field conditions. Horticulture Science 33, 826-829.

Pickering, I.J., George, M.J., Smith, R.D. et al., 2000. Reduction and coordination of arsenic in Indian Mustard. Plant Physiology 122, 1171-1177.

Pigna, M., Cozzolino, V., Violante, A., Meharg, A.A., 2009. Influence of Phosphate on the Arsenic Uptake by Wheat (Triticum durum L.) Irrigated with Arsenic Solutions at Three Different Concentrations. Water Air and Soil Pollution 197, 371-380.

Pigna, M., Cozzolino, V., Caporale, A.G., Mora, M.L., Di Meo, V., Jara, A.A., et al., 2010. Effects of phosphorus fertilization on arsenic uptake by wheat grown in polluted soils. Journal of Soil Science and Plant Nutrition 10, 428-442.

Pigna, M., Caporale, A.G., Cozzolino, V., Fernández-López, C., Mora, M.L., Sommella, A. Violante, A., 2012. Influence of phosphorus on the arsenic uptake by tomato(Solanum lycopersicum L) irrigated with arsenic solutions at four different concentrations. Journal of Soil Science and Plant Nutrition 12, 775-784.

Planas, D., Healey, F.P., 1978. Effects of arsenate on growth and phosphorus metabolism of phytoplankton. Journal of Phycology 14, 337-341.

Pollard, A.J., Powell, K.D., Harper, F.A., Smith, J.A.C., 2002. The genetic basis of metal hyperaccumulation in plants. Critical Reviews in Plant Science 21, 539-566.

Porter, E.K., Peterson, P.J., 1977. Arsenic resistance in grasses growing on mine waste. Environmental Pollution 14, 255-265. 
Pratas, J., Prasad, M.N.V., Freitas, H., Conde, L., 2005. Plants growing in abandoned mines of Portugal are useful for biogeochemical exploration of arsenic, antimony, tungsten and mine reclamation. J Geochem Explor, 85, 99-107.

Puckett, E.E., Serapiglia, M.J., DeLeon, A.M., Long, S., Minocha, R., Smart, L.B., 2012. Differential expression of genes encoding phosphate transporters contributes to arsenic resistance and accumulation in shrub willow (Salix spp.). Environmental and Experimental Botany 75, 248- 257.

Qin, J., Rosen, B.P., Zhang, Y., Wang, G., Franke, S., Rensing, C., 2006. Arsenic detoxification and evolution of trimethylarsine gas by a microbial arsenite Sadenosylmethionine methyltransferase. Proceedings of National Academy of Science, USA 103, 2075-2080.

Quaghebeur, M., Rengel, Z., Smirk, M., 2003. Arsenic speciation in terrestrial plant material using microwave-assisted extraction, ion chromatography and inductively coupled plasma mass spectrometry. Journal of Analytical and Atomic Spectrometry 18, 128-34.

Quaghebeur, M., Rengel, Z., 2003. The distribution of As(V) and As(III) in shoots and roots of Holcus lanatus is influenced by arsenic resistance and $\mathrm{As}(\mathrm{V})$ and phosphate supply. Plant Physiology 132, 1600-1609.

Quaghebeur, M., Rengel, Z., 2004.Phosphate and As(V) interactions in the rhizosphere of canola (Brassica napus). Functional Plant Biology 31, 1085-1094.

Quaghebeur, M., Rate, A., Rengel, Z., Hinz, C., 2005. Desorption kinetics of arsenate from kaolinite as influenced by pH. Journal of Environmental Quality 34, 479-86.

Quaghebeur, M., Rengel, Z., 2005. Arsenic speciation governs arsenic uptake and transport in terrestrial plants. Microchimica Acta 151, 141-52.

Raab, A., Feldmann, J., Meharg, A.A., 2004. The nature of arsenic-phytochelatin complexes in Holcus lanatus and Pteris cretica. Plant Physiology 134, 1113-1122.

Rahman, M.A., Hasegawa, H., Rahman, M.M., Islam, M.N., Miah, M.A.M., Tasmen, A., 2007. Effect of arsenic on photosynthesis, growth and yield of five widely cultivated rice (Oryza sativa L.) varieties in Bangladesh. Chemosphere 67, 1072-1079.

Rahman, M.A., Hasegawa, H., Rahman, M.M., Miah, M.A.M., Tasmen, A., 2008. Straighthead disease of rice (Oryza sativa L.) induced by arsenic toxicity. Environmental and Experimental Botany 62, 54-59.

Rauf, MA, Hakim, MA, Hanafi, MM, Islam, MM, Rahman, GKMM, Panaullah, GM, 2011. Bioaccumulation of arsenic (As) and phosphorous by transplanting Aman rice in arseniccontaminated clay soils. Australian Journal of Crop Science 5, 1678-1684. 
Rausch, C., Bucher, M., 2002. Molecular mechanisms of phosphate transport in plants. Planta 216, 23-37.

Reina, S.V., Esteban, E., Goldsbrough, P., 2005. Arsenate-induced phytochelatins in white lupin: influence of phosphate status. Physiologia Plantarum 124, 41-49.

Remy, E., Cabrito, T.R., Batista, R.A., Teixeira, M.C., Sa-Correia, I., Duque, P., 2012. The Pht 1;9 and Pht 1;8 transporters mediate inorganic phosphate acquisition by the Arabidopsis thaliana root during phosphorus starvation. New Phytologist 195, 356-371.

Rose, T.J., Impa, S.M., Rose, M.T., Pariasca-Tanaka, J., Mori, A., Heuer, S., JohnsonBeebout, S.E., Wissuwa, M., 2013. Enhancing phosphorus and zinc acquisition efficiency in rice: a critical review of root traits and their potential utility in rice breeding. Annals of Botany 112, 331-345.

Rouached, H., Arpat, A.B., Poirier, Y., 2010. Regulation of phosphate starvation responses in plants: signaling players and cross-talks. Molecular Plant 3, 288-299.

Roy, W.R., Hassett, J.J., Griffin, R.A., 1986. Competitive interactions of phosphate and molybdate on arsenate adsorption. Soil Science 142, 203-210.

Rumberg, C.B., Engel, R.E., Meggitt, W.F., 1960. Effect of phosphorus concentration on the absorption of arsenate by oats from nutrient solution. Agronomy Journal 52, 452-453.

Salmon, S.U., Rate, A.W., Rengel, Z., Appleyard, S., Prommer, H., Hinz, C., 2014. Reactive transport controls on sandy acid sulfate soils and impacts on shallow groundwater quality. Water Resources Research 50, 4924-4952.

Sanchary, I.J., Huq, S.M.I., 2017. Remediation of arsenic toxicity in the soil-plant system by using zinc fertilizers. Journal of Agricultural Chemistry and Environment 6, 30-37.

Santos, J.A.G., Gonzaga, M.I.S., Ma, L.Q., Srivastava, M., 2008. Timing of phosphate application affects arsenic phytoextraction by Pteris vittata L. of different ages. Environmental Pollution 154, 306-311.

Schachtman, D.P., Reid, R.J., Ayling, S.M., 1998. Phosphorus uptake by plants: from soil to cell. Plant Physiology 116, 447-453.

Schunmann, P.D., Richardson, A.D., Vickers, C.E., Delhaize, E., 2004a. Promoter analysis of the barley Pht1;1 phosphate transporter gene identifies regions controlling root expression and responsiveness to phosphate deprivation. Plant Physiology 136, 4205-4214.

Schunmann, P.D., Richardson, A.D., Smith, F.W., Delhaize, E., 2004b. Characterization of promoter expression patterns derived from the Pht1 phosphate transporter genes of barley (Hordeum vulgare L.). Journal of Experimental Botany 55, 855-865. 
Shaibur, M.R., Adjadeh, T.A., Kawai, S., 2013. Effect of phosphorus on the concentrations of arsenic, iron and some other elements in barley grown hydroponically. Journal of Soil Science and Plant Nutrition 13, 87-98.

Sharma, S., Anand, G., Singh, N., Kapoor, R., 2017. Arbuscular Mycorrhiza augments arsenic tolerance in wheat (Triticum aestivum L.) by strengthening antioxidant defense system and thiol metabolism. Frontiers in Plant Science 8, 906.

Sharples, J.M., Meharg, A.A., Chambers, S.M., Cairney, J.W.G., 1999. Arsenate sensitivity in ericoid and ectomycorrhizal fungi. Environmental Toxicology and Chemistry 18, 18481855.

Sharples, J.M., Meharg, A.A., Chambers, S.M., Cairney, J.W.G., 2000a. The symbiotic solution to arsenic contamination. Nature 404, 951-952.

Sharples, J.M., Meharg, A.A., Chambers, S.M., Cairney, J.W.G., 2000b. Mechanism of arsenate resistance in the ericoid mycorrhizal fungus Hymenoscyphus ericae. Plant Physiology 124, 1327-1334.

Shetty, K.G., Hetrick, B.A.D., Schwab, A.P., 1995. Effects of mycorrhizae and fertilizer amendments on zinc resistance of plants. Environmental Pollution 88, 307-314.

Shin, H., Shin, H.S., Dewbre, G.R., Harrison, M.J., 2004. Phosphate transport in Arabidopsis: Pht 1;1 and Pht1;4 play a major role in phosphate acquisition from both low- and highphosphate environments. Plant Journal 39, 629-642.

Singh, N., Ma, L.Q., 2006. Arsenic speciation, and arsenic and phosphate distribution in arsenic hyperaccumulator Pteris vittata L. and non-hyperaccumulator Pteris ensiformis L. Environmental Pollution 141, 238-246.

Shoji, R., Yajima, R., Yano, Y., 2008. Arsenic speciation for the phytoremediation by the Chinese brake fern, Pteris vittata. Journal of Environmental Science 20, 1463-1468.

Smith, E., Naidu, R., Alston, A.M., 1998. Arsenic in the soil environment: A review. Advances in Agronomy 64, 149-195.

Smith, E., Naidu, R., Alston, A.M., 2002. Chemistry of inorganic arsenic in soils. II. Effect of phosphorus, sodium, and calcium on arsenic absorption. Journal of Environmental Quality $31,557-563$.

Smith, S.E., Smith, F.A., Jakobsen, I., 2003. Mycorrhizal fungi can dominate phosphate supply to plants irrespective of growth responses. Plant Physiology 133, 16-20.

Smith, S.E., Smith, F.A., Jakobsen, I., 2004. Functional diversity in arbuscular mycorrhizal (AM) symbioses: the contribution of the mycorrhizal P uptake pathway is not correlated with mycorrhizal responses in growth or total P uptake. New Phytologist 162, 511-524. 
Smith, S.E., Read, D.J., 2008. Mycorrhizal Symbiosis. Academic Press, New York, London, Burlington, San Diego.

Smith, S.E., Christophersen, H.M., Pope, S., Smith, F.A., 2010. Arsenic uptake and toxicity in plants: integrating mycorrhizal influences. Plant and Soil 327, 1-21.

Sneller, E.F.C., Van Heerwaarden, L.M., Kraaijeveld-Smit, F.J.L., Ten Bookum, W.M., Koevoets, P.L.M., Schat, H, et al., 1999. Toxicity of As(V) in Silene vulgaris, accumulation and degradation of As(V) induced phytochelatins. New Phytologist 44, 223 232.

Srivastava, M., Santos, J., Srivastava, P., Ma, L.Q., 2010. Comparison of arsenic accumulation in 18 fern species and four Pteris vittata accessions. Bioresource Technology 101, 2691-2699.

Szegedi, K., Vetterlein, D., Jahn, R., 2010. Modelling rhizosphere transport in the presence of goethite, including competitive uptake of phosphate and As(V). Plant and Soil 330, 481501.

Tao, Y., Zhang, S., Jian, W., Yuan, C., Shan, X.-Q., 2006. Effects of oxalate and phosphate on the release of arsenic from contaminated soils and arsenic accumulation in wheat. Chemosphere 65, 1281-1287.

Talukder, A.S.M.H.M., Meisner, C.A., Sarkar, M.A.R., Islam, M.S., 2011. Effect of water management, till age option s and phosphorus status on arsenic uptake in rice. Ecotoxicology and Environmental Safety 74, 834-839.

Talukder, A.S.M.H.M., Meisner, C.A., Sarkar, M.A.R., Islam, M.S., Sayre, K.D., Duxbury, J.M., Lauren, J.G., 2012. Effect of water management, arsenic and phosphorus levels on rice in a high-arsenic soil-water system: II. Arsenic uptake. Ecotoxicology and Environmental Safety 80, 145-151.

Taylor, G.J., Crowder, A.A., Rodden, R., 1984. Formation and morphology of iron plaque on the roots of Typha latifolia L. growing in solution culture. American Journal of Botany 71, 666-1675.

Tu, S., Ma, L.Q., 2003a. Effects of As(V) and phosphate on their accumulation by an arsenichyperaccumulator Pteris vittata L. Plant and Soil 249, 373-382.

Tu, S., Ma, L.Q., 2003b. Interactive effects of pH, arsenic and phosphorus on uptake of As and $\mathrm{P}$ and growth of the arsenic hyperaccumulator Pteris vittata $\mathrm{L}$. under hydroponic conditions. Environmental and Experimental Botany 50, 243-251. 
Tu, S., Ma, L.Q., MacDonald, G.E., Bondada, B., 2004. Effects of arsenic species and phosphorus on arsenic absorption, $\mathrm{As}(\mathrm{V})$ reduction and thiol formation in excised parts of Pteris vittata L. Environmental and Experimental Botany 51, 121-131.

Tuan, L.Q., Huong, T.T.T., Hong, P.T.A., Kawakami, T., Shimanouchi, T., Umakoshi. H., Kuboi, R., 2008. Arsenic (V) induces a fluidization of algal cell and liposome membranes. Toxicology In Vitro 22, 1632-1638.

Turnau, K., Kottke, I., Oberwinkler, F., 1993. Element localization in mycorrhizal roots of Pteridium aquilinum (L.) collected from experimental plots treated with cadmium dust. New Phytologist 123, 313-324.

Ullrich-Eberius, C.I., Sanz, A., Novacky, A.J., 1989. Evaluation of arsenate- and vanadateassociated changes of electrical membrane potential and phosphate transport in Lemna gibba L. Journal of Experimental Botany 40:119-128.

Ultra Jr., V.U., Tanaka, S., Sakurai, K., Iwasaki, K., 2007. Effects of arbuscular mycorrhiza and phosphorus application on arsenic toxicity in sunflower (Helianthus annuus L.) and on the transformation of arsenic in the rhizosphere. Plant and Soil 290, 29-41.

Vetterlein, D., Szegedi, K., Ackermann, J., Mattusch, J., Neue, H.-U., Tanneberg, H., Jahn R., 2007. Competitive mobilization of phosphate and $\mathrm{As}(\mathrm{V})$ associated with goethite by root activity. Journal of Environmental Quality 36, 1811-1820.

Vetterlein, D., Jahn, R., Mattusch, J., 2009. Comparison of corn and lupin in respect to As mobilisation, uptake and release in an arsenic contaminated floodplain soil. Proceeding of Internatiol Plant Nutrition Colloquim XVI, 2009.

Violante, A., Pigna, M., 2002. Competitive sorption of As(V) and phosphate on different clay minerals and soils. Soil Science Society of America Journal 66, 1788-1796.

Walsh, L., Keeney, D., 1975. Behavior and phytotoxicity of inorganic arsenicals in soils. In: EA Woolson (ed) Arsenical Pesticides, ACS Symposium Series 7, American Chemical Society. Washington, DC.

Wang, J., Zha, F.-J., Meharg, A.A., Raab, A., Feldmann, J., McGrath, S.P., 2002. Mechanisms of arsenic hyperaccumulation in Pteris vittata. Uptake kinetics, interactions with phosphate, and arsenic speciation. Plant Physiology 130, 1552-1561.

Wang G, Kennedy SP, Fasiludeen S, Rensing C, DasSarma S (2004) Arsenic resistance in Halobacterium sp. strain NRC-1 examined by using an improved gene knockout system. Journal of Bacteriology 186, 3187-3194. 
Wenzel, W.W., Brandstetter, A., Wutte, H., Lombi, E., Prohaska, T., Stingeder, G., Adriano, D.C., 2002. Arsenic in field-collected soil solutions and extracts of contaminated soils and its implication to soil standards. Journal of Plant Nutrition and Soil Science 165, 221-228.

Woolson, E.A., 1973. Arsenic phytotoxicity and uptake in six vegetable crops. Weed Science $21,524-527$.

Xia, Y.-S., Chen, B.-D., Christie, P., Smith, F.A., Wang, Y.S., Li, X.-L., 2007. Arsenic uptake by arbuscular mycorrhizal maize (Zea mays L.) grown in an arsenic-contaminated soil with added phosphorus. Journal of Environmental Science 19, 1245-1251.

Xiong J, Wu L, Tu S, Van Nostrand JD, He Z, Zhou J, Wang G (2010) Microbial communities and functional genes associated with soil arsenic contamination and the rhizosphere of the arsenic-hyperaccumulating plant Pteris vittata L. Applied and Environmental Microbiology 76, 7277-7284.

Xu, P.L., Christie, P., Liu, Y., Zhang, J.L., Li, X.L., 2008. The arbuscular mycorrhizal fungus Glomus mosseae can enhance arsenic resistance in Medicago truncatula by increasing plant phosphorus status and restricting arsenate uptake. Environmental Pollution 156, 215220.

Yan, X., Zhang, M., Liao, X., Tu, S., 2012. Influence of amendments on soil arsenic fractionation and phytoavailability by Pteris vittata L. Chemosphere 88, 240-244.

Ye, W.-L., Khan, M. A., McGrath, S.P., Zhao, F.-J., 2011. Phytoremediation of arsenic contaminated paddy soils with Pteris vittata markedly reduces arsenic uptake by rice. Environmental Pollution 159, 3739-3743.

Zhao, F.J., Ma, J.F., Meharg, A.A., McGrath, S.P. 2009. Arsenic uptake and metabolism in plants. New Phytologist 181, 777-794.

Zhu, Y.-G., Smith, F.A., Smith, S.E., 2003. Phosphorus efficiencies and responses of barley (Hordeumvul-gare L.) to arbuscular mycorrhizal fungi grown in highly calcareous soil. Mycorrhiza 13, 93-100.

Zhu, Y.-G., Geng, C.-N., Tong, Y.-P., Smith, S.E., Smith, F.A., 2006. Phosphate (Pi) and As(V) uptake by two wheat (Triticum aestivum) cultivars and their doubled Haploid Lines. Annals of Botany 98, 631-636.

Zou Q, Liu F, Yang J-H (2009) Adsorption-desorption and competitive adsorption of arsenic and phosphorus in purple soil. Journal of Applied Ecology 20, 1383-1389.

Zupancic, M., Lavrič, S., Bukovec, P., 2012. Metal immobilization and phosphorus leaching after stabilization of pyrite ash contaminated soil by phosphate amendments. Journal of Environmental Monitoring 14, 704-710. 


\section{Figure captions}

969

970 Fig. 1. As-Pi interactions and uptake by plants in hydroponics. As and Pi supply variably

971 control As and Pi uptake by plant roots. Pi supply strongly decreases As uptake, while As

972 supply weakly decreases Pi uptake. Pi has higher affinity for plan roots than As.

973

974 Fig. 2. Mean shoot biomass, As and P concentrations in shoots and total As uptake by wheat

975 plants grown in soil irrigated with As containing water at three concentrations amended and

976 non-amended with P (data analysis from Pigna et al., 2009).

977

978 Fig. 3. Role of AM in modifying As-Pi interactions, and As and Pi uptake by plant root. The 979 arbuscular mycorrhizal (AM) symbioses increase Pi uptake by plant roots and $\mathrm{Pi} / \mathrm{As}$ ratio in 980 shoot, while they decrease As uptake by roots. 
Table 1

Effects of competition between As and Pi on uptake by plants grown in soil.

\begin{tabular}{|c|c|c|c|c|}
\hline Soil types & Plant species & Addition & Effect & Reference \\
\hline Soil & Zea mays & $\mathrm{Fe}(1-4 \mathrm{~g} / \mathrm{kg})$ & $\begin{array}{l}\text { At low goethite - low As/high P uptake. At high goethite - no As/Pi } \\
\text { uptake }\end{array}$ & Vetterlein et al. (2007) \\
\hline $\begin{array}{l}\text { Silt loam/ } \\
\text { sand }\end{array}$ & Zea mays & $\begin{array}{l}\mathrm{Pi}(50-300 \\
\mathrm{mg} / \mathrm{kg})\end{array}$ & $\begin{array}{l}\text { Pi had little effect on As toxicity to plants in silt loam, but enhanced } \\
\text { As uptake and toxicity in sand at } 80 \mathrm{mgAs} / \mathrm{kg}\end{array}$ & $\begin{array}{l}\text { Jacobs and Keeney } \\
(1970)\end{array}$ \\
\hline Soil & Pteris vittata & $\begin{array}{l}\text { As }(2.7- \\
5.3 \mathrm{mM})\end{array}$ & $\begin{array}{l}\text { Low As increased Pi uptake, but high As decreased Pi uptake. Pi } \\
\text { increased plant biomass and As uptake at high As supply }\end{array}$ & $\begin{array}{l}\text { Tu and Ma (2003a), } \\
\text { Kertulis et al. (2005) }\end{array}$ \\
\hline Soil & Oryza sativa & $\mathrm{Pi}$ & Increasing shoot Pi for breeding rice with low grain As & Lu et al. (2010) \\
\hline Soil & Oryza sativa & $\begin{array}{l}\mathrm{Pi}(0-0.5 \\
\mathrm{mM})\end{array}$ & $\begin{array}{l}\text { Suppressed } \mathrm{As}(\mathrm{V}) \text {, but not } \mathrm{As}(\mathrm{III}) \text { uptake; little difference in As } \\
\text { uptake between two P-deprived rice genotypes }\end{array}$ & $\begin{array}{l}\text { Abedin et al. (2002), } \\
\text { Geng et al. (2006) }\end{array}$ \\
\hline Clay loam & T. durum & $\mathrm{Pi}(75 \mathrm{~kg} / \mathrm{ha})$ & Prevented As uptake and translocation in plants & Pigna et al. (2010) \\
\hline Soil & H. vulgare & $\mathrm{Pi} / \mathrm{As}$ & Pi strongly inhibited As(V) uptake. As weakly inhibited Pi uptake & Asher and Reay(1979) \\
\hline $\begin{array}{l}\text { Soil-sand, } \\
\text { soil }\end{array}$ & $\begin{array}{l}\text { H. vulgare } \\
\text { T. vulgare }\end{array}$ & $\begin{array}{l}\mathrm{Pi}(20-120 \\
\mathrm{mg} / \mathrm{kg})\end{array}$ & $\begin{array}{l}\text { Increased As uptake; decreased As(V) toxicity not by lowering As } \\
\text { uptake, but by emhancing Pi nutrition. No competition between As } \\
\text { and Pi. }\end{array}$ & $\begin{array}{l}\text { Christophersen et al. } \\
(2009 \mathrm{a}), \text { Tao et al. } \\
(2006)\end{array}$ \\
\hline Soil & C. arietinum & $\mathrm{Pi}(50-400)$ & $\begin{array}{l}\text { Pi increased As uptake, but partially protected membranes from } \\
\text { damage }\end{array}$ & Gunes et al. (2009) \\
\hline Soil & L. cinereus & $\mathrm{As} / \mathrm{Pi}$ & High level of As and low Pi supply decreased plant growth & Knudson et al. (2003) \\
\hline Loam soil & P. armeniaca & $\mathrm{Pi}$ & $\begin{array}{l}\text { Increased shoot and root As in soil contaminated with } \mathrm{Pb} \text {-arsenate } \\
\text { pesticide residue. }\end{array}$ & $\begin{array}{l}\text { Creger \& Peryea } \\
(1994)\end{array}$ \\
\hline Soil & $\begin{array}{l}\text { Arabidopsis } \\
\text { thaliana }\end{array}$ & $\begin{array}{l}\mathrm{Pi}(10-40 \\
\mathrm{mg} / \mathrm{kg})\end{array}$ & $\begin{array}{l}\text { Low Pi supply increased As uptake and plant growth. High Pi } \\
\text { supplydecreased As uptake due to competition on surface of soil } \\
\text { particles and plant roots. }\end{array}$ & Geng et al. (2005) \\
\hline Soil & $\begin{array}{l}\text { Solanum } \\
\text { lycopersicum }\end{array}$ & $\begin{array}{l}\text { Pi }(6 \mathrm{mM}) \text {, } \\
\text { As }(4 \mathrm{mg} / \mathrm{L})\end{array}$ & $\begin{array}{l}\text { Pi was more strongly adsorbed to soil than As(V), Pi desorbed As } \\
\text { and increased As uptake by plants depending on soil charge } \\
\text { properties }\end{array}$ & $\begin{array}{l}\text { Pigna et al. (2012), } \\
\text { Bolan et al. (2013) }\end{array}$ \\
\hline Soil & H. lanatus & $\mathrm{Pi}(0.2 \mathrm{~g} / \mathrm{kg})$ & $\begin{array}{l}\text { Increased As uptake by plant because of increased As desorption by } \\
\text { competition }\end{array}$ & $\begin{array}{l}\text { Lewińska and } \\
\text { Karczewska (2013) }\end{array}$ \\
\hline Soil & Plants & $\mathrm{Pi}$ & $\begin{array}{l}\text { Enhanced } \mathrm{As}(\mathrm{V}) \text { and } \mathrm{As}(\amalg) \text { desorption from soil and thus leaching } \\
\text { or uptake by plants }\end{array}$ & Fitz and Wenzel, 2002 \\
\hline
\end{tabular}




\begin{tabular}{|l|l|l|l|l|l|}
\hline As-Soil & Vegetable & $\mathrm{Pi}(3867)$ & Increased As uptake- 4.6-9.3 times forcarrot, 2.5-10for lettuce & Cao and Ma (2004) \\
\hline Soil & No plants & $\mathrm{Pi} / \mathrm{As}$ & $\begin{array}{l}\text { At As:Pi ratio equal to 1, more Pi was sorbed than As. At As:Pi } \\
\text { ratios > 1, Pi was desorbed due to a mass action effect }\end{array}$ & Woolson et al. (1973) \\
\hline $\begin{array}{l}\text { Fe-soil } \\
\text { /mine soil }\end{array}$ & No plants & $\mathrm{Pi}$ & $\begin{array}{l}\text { Reduced As(V) sorption to low Fe oxide soils and increased As } \\
\text { mobility by competitive adsorption }\end{array}$ & $\begin{array}{l}\text { Zupancic et al. (2012), } \\
\text { Smith et al. (2002) }\end{array}$ \\
\hline
\end{tabular}

\section{Table 2}

Effect of competition between As and Pi on uptake by plants in hydroponics.

\begin{tabular}{|l|l|l|l|}
\hline Plant species & Addition & \multicolumn{1}{|c|}{ Effect } & \multicolumn{1}{|c|}{ References } \\
\hline Pteris vittata & $\mathrm{Pi}(0.1-2 \mathrm{mM})$ & $\begin{array}{l}\text { High Pi decreased As(V) but not As(III) accumulation in } \\
\text { roots/shoot; it enhanced As(V) reduction; high As(V) decreased } \\
\text { Pi uptake }\end{array}$ & $\begin{array}{l}\text { Lou et al. (2010), Tu et al. } \\
\text { (2004), Wang et al. (2002) }\end{array}$ \\
\hline Oryza sativa & $\mathrm{Pi}, 0.1 \mathrm{mM}$ & $\begin{array}{l}\text { High Pi concentration decreased As uptake; high As } \\
\text { concentration slightly decreased Pi uptake }\end{array}$ & Lihong and Guilan (2009) \\
\hline Holcus lanatus & $\mathrm{Pi}$ & $\begin{array}{l}\text { Decreased As(V) uptake in nonresistant, but less in resistant } \\
\text { plants }\end{array}$ & Meharg \& MacNair (1992) \\
\hline Lemna gibba & $\mathrm{Pi}, 40 \mathrm{mg} / \mathrm{L}$ & High Pi reduced As(V, III) uptake; high As reduced Pi uptake & Mkandawire et al. (2004) \\
\hline M.sativa & $\mathrm{Pi}$ & Strongly suppressed As uptake & Khattak et al. (1991) \\
\hline Silene vulgaris & $\mathrm{Pi}, 0.3-3 \mathrm{mg} / \mathrm{L}$ & $\begin{array}{l}\text { As supply did not influence root growth at high Pi, but did at low } \\
\text { Pi supply }\end{array}$ & Sneller et al. (1999) \\
\hline Avena sativa & $\mathrm{Pi}$ & Decreased As(V) uptake, but little effect on As(III) uptake. & Rumberg et al. (1960) \\
\hline Glycine max & $\mathrm{As}, 32-96 \mu \mathrm{M}$ & Decreased Pi content in soybean organs & Milivojevic et al.(2006) \\
\hline T. aestivum & $\mathrm{Pi}$ & High-affinity uptake system switched on at 25 mM Pi. & Zhu et al. (2006) \\
\hline
\end{tabular}






Fig. 1. As-Pi interactions and uptake by plants in hydroponics. As and Pi supply variably control As and Pi uptake by plant roots. Pi supply strongly decreases As uptake, while As supply weakly decreases Pi uptake. Pi has higher affinity for plan roots than As.

Fig. 2. Mean shoot biomass, As and Pi concentrations in shoots and total As uptake by wheat plants grown in soil irrigated with As containing water at three concentrations amended and non-amended with Pi (data analysis from Pigna et al., 2009).

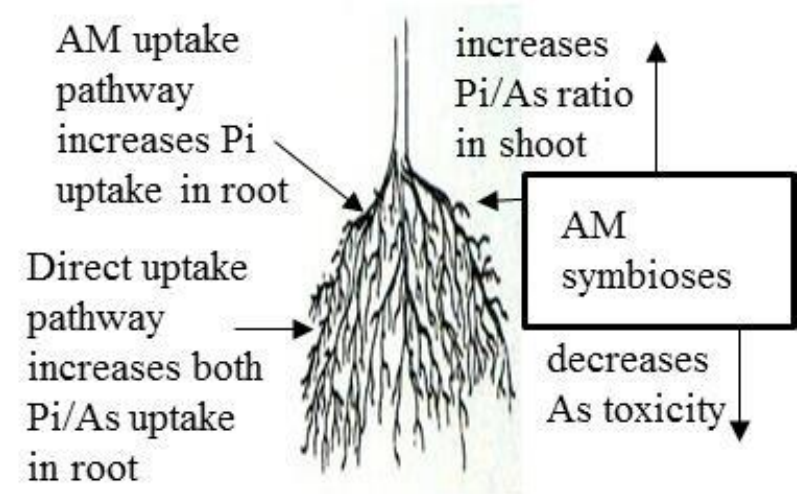

Fig. 3. Role of AM in modifying As-Pi interactions, and As and Pi uptake by plant root. The arbuscular mycorrhizal (AM) symbioses increase Pi uptake by plant roots and $\mathrm{Pi} / \mathrm{As}$ ratio in shoot, while they decrease As uptake by roots. 